\title{
Proposing a Theoretical and State-of- the-Art Didactic Model to Balance Oral Communication Fluency and Accuracy in English as a Foreign Language ${ }^{[1]}$
}

González Robaina, Yaynel; Díaz Larenas, Claudio

Proposing a Theoretical and State-of-the-Art Didactic Model to Balance Oral Communication Fluency and Accuracy in English as a Foreign Language ${ }^{[1]}$

Revista Educación, vol. 44, núm. 1, 2020

Universidad de Costa Rica, Costa Rica

Disponible en: http://www.redalyc.org/articulo.oa?id=44060092012

DOI: https://doi.org/10.15517/revedu.v44i1.36873

Esta obra está bajo una Licencia Creative Commons Atribución-NoComercial-SinDerivar 3.0 Internacional. 


\title{
Proposing a Theoretical and State-of-the-Art Didactic Model to Balance Oral Communication Fluency and Accuracy in English as a Foreign Language ${ }^{[1]}$
}

\author{
Propuesta de un Modelo Didáctico Basado en la Teoría y el Estado del Arte para Equilibrar Fluidez y Precisión en la \\ Comunicación Oral en Inglés como Lengua Extranjera ${ }^{[2]}$
}

Yaynel González Robaina

Universidad de Concepción, Chile

Universidad de Matanzas, Cuba

yaynel.gonzalez@gmail.com

(iD http://orcid.org/0000-0002-5196-3240

Claudio Díaz Larenas

Universidad de Concepción, Chile

claudiodiaz@udec.cl

D http://orcid.org/0000-0002-9024-2497
DOI: https://doi.org/10.15517/revedu.v44i1.36873 Redalyc: http://www.redalyc.org/articulo.oa?id=44060092012

Recepción: 25 Abril 2019

Aprobación: 20 Septiembre 2019

\begin{abstract}
:
The profile of English as a Foreign Language (EFL) teachers education programs in Chile requires graduates to communicate effectively and master phonetic-phonological, lexical, morpho-syntactic, semantic, and pragmatic aspects of the English language. Graduates should possess an advanced level of oral proficiency which entails an adequate balance of fluency and accuracy in oral communication. Attaining a correct balance between oral fluency and accuracy from the start of EFL pre-service teachers training programs is currently a goal of Chilean Universities. The objective of this article is to propose a theory-based didactic model to address and overcome first year Chilean EFL pre-service teachers' constraints regarding fluency and accuracy in oral communication development. The proposed didactic model is based on a theoretical revision of such constructs in Second Language Teaching (SLT) literature. The proposed model contributes to the developing research that can support the progress of fluency and accuracy in EFL pre-service teachers' oral communication, which is limited by Second/Foreign Language Teaching theories, methodologies and approaches which require further study.
\end{abstract}

KeYwords: Fluency, Accuracy, Oral Communication, Didactic Model, English as a Foreign Language.

\section{ReSUMEN:}

El perfil profesional de los programas de educación de profesores de inglés como lengua extranjera en Chile, exige que los graduados se comuniquen de manera efectiva y dominen los aspectos fonético-fonológicos, léxicos, morfosintácticos, semánticos y pragmáticos del idioma inglés a un nivel avanzado de competencia oral. Todo lo cual presupone un equilibrio adecuado entre fluidez y precisión en la comunicación oral. Por lo tanto, proporcionar el equilibrio correcto entre la fluidez y la precisión oral a los profesores de inglés en formación desde el año académico básico, es un desafío actual para los docentes universitarios chilenos que imparten el inglés como lengua extranjera. En esta dirección, el objeto de estudio de este artículo es el desarrollo de la comunicación oral en inglés como lengua extranjera. Consecuentemente, este artículo tiene como objetivo principal: proponer un modelo didáctico basado en la teoría para equilibrar la fluidez y la precisión en el desarrollo de la comunicación oral en inglés como lengua extranjera en los estudiantes de primer año de formación de la carrera pedagogía en inglés en Chile. El modelo didáctico propuesto por los autores del presente artículo, se basa en una revisión teórica y del estado del arte de dichos constructos en la literatura sobre la enseñanza y adquisición de segundas lenguas. En conclusiones, el modelo figura como evidencia de investigaciones emergentes que pueden contribuir al progreso del equilibrio de la fluidez y la precisión en la comunicación oral en inglés como lengua extranjera; problemática que se ha visto limitada por las teorías, metodologías y enfoques de la enseñanza de segundas lenguas/ lenguas extranjeras y que aún necesita más estudio.

Palabras ClaVe: Fluidez, Precisión, Comunicación oral, Modelo didáctico, Inglés como lengua extranjera. 


\section{INTRODUCTION}

Second Language Acquisition (SLA) has been thoroughly addressed by Applied Linguistics researchers. Initially, research focused mainly on natural acquisition processes since language acquisition in the classroom was considered to be of little relevance (Doughty \& Williams, 2009). Today, researchers (Doughty \& Williams, 2009; Ellis, 2009; Nation, 2011; Richards \& Rodgers, 2001) have increasingly focused on Second Language Teaching (SLT) including Focus on Form, task planning, approaches and methods implementation. According to Littlewood (2004), improving foreign language teaching-learning processes has been a research objective dating back to the 1960 's in an effort to respond to today's global sociocultural demands.

Chile has focused on teaching English as a Foreign Language (EFL) for two main reasons: 1) Chilean society is now immersed in an international sphere where English is the language of the globalized world, and 2) Chile has a low level of oral proficiency in English (Lizasoain, Ortiz de Zárate, Véliz, Luci, \& Rojas, 2016; Yilorm, 2016). Consequently, according to the professional profile of EFL teachers education programs in Chile, graduates must be able to communicate effectively and master the phonetic-phonological, lexical, morpho-syntactic, semantic, and pragmatic aspects of the English language and demonstrate an advanced level of oral proficiency. All of these abilities require attaining an adequate balance of both fluency and accuracy in oral communication.

It is, therefore, important for EFL pre-service teachers to balance oral fluency and accuracy during their freshman year at Chilean EFL teachers education programs. This article proposes a theory-based didactic model to resolve Chilean EFL university teachers' constraints in addressing fluency and accuracy among first year EFL pre-service teachers and help learners attain adequate levels of oral proficiency.

\section{Oral Proficiency}

Housen and Kuiken (2009) state that during the eighties, SLT research distinguished between fluent and accurate second language (L2) use in order to research oral L2 proficiency in classroom contexts. Accuracy is defined as "the ability to produce error-free speech" (Lennon, 1990, p. 390), and fluency as "the ability to process the L2 with 'native-like rapidity" (Lennon, 1990, p. 390). Later, in the nineties, a third construct, complexity, was added to complete the triad which we refer to as oral proficiency today. Complexity is defined as "the extent to which the language produced in performing a task is elaborate and varied" (Ellis, 2003, p. 340). Oral proficiency is defined as a construct which requires great effort by the speaker in order to produce error-free language. It should be noted that this article will be limited solely to constructs regarding fluency and accuracy since the proposed didactic model is intended for first year Chilean EFL pre-service teachers and oral language complexity is not fully addressed during this stage of training.

\section{Fluency in Oral Communication}

Despite the extensive amount of research on oral communication fluency, there is still a relative lack of consistency among (Karimy \& Pishkar, 2017; Požgaj, Horga \& Balazic, 2012; Segalowitz \& Freed, 2004) Applied Linguistics researchers in defining this construct. Oral fluency "refers to those aspects of oral performance having to do with the fluidity or 'smoothness' of language use" (Segalowitz \& Freed, 2004, p. 175). Oral fluency is also described as "a measure of how well and how easily you can communicate your ideas clearly and accurately in speech" (Karimy \& Pishkar, 2017, p. 49). Thus, fluency may also include accurate use of oral language, which implies an inadequate division between the terms of fluency and accuracy, which can be confusing. Oral fluency is also defined as: 
Speech at a natural rate without hesitations, pauses, repetitions, reformulations, filler words and filled or unfilled pauses in processing, appropriate to the informative and communicative load of expression, all of which presuppose efficient and coordinated functioning of all levels of oral production. (Požgaj et al., 2012, p. 88)

Lack of consistency among the aforementioned definitions of oral fluency triggered the following question: What is oral communication fluency? A theoretical review on oral fluency allowed us to classify the different factors into three categories that influence oral fluency among EFL language learners: 1) individual factors: working memory capacity, age, character traits, intelligibility, language aptitude, motivation; 2) prosodic elements: accent, intonation, pronunciation, rhythm, sound articulation, and 3) educational and cultural level: knowledge about a variety of topics, accessibility to a wide range of vocabulary and grammar structures, and academic speech performance. Therefore, oral fluency can be defined as a multifactorial construct which demands cognition, aptitude, motivation, and experience in EFL language processing and performance. Oral fluency is comprised of many variables, making it a complex construct in Second/Foreign Language teaching and research, leading to a variety of results and definitions.

Consequently, there is no evidence of successful models to support L2 oral fluency training. However, Nation (2011) claims that fluency development requires the following conditions: 1) fluency needs to be skill specific, speaking fluency practice is required to improve speaking fluency; 2) the material worked with must be very familiar to learners, there should be no unfamiliar vocabulary, grammatical structures, or discourse features contained in the task; 3 ) the tasks should be communicative in nature and should focus on conveying messages and 4) fluency development also requires practice and repetition, the more practice, the greater the attained fluency. All of these conditions were considered in developing the proposed didactic model for first year Chilean EFL pre-service teachers. Conditions one and three were integrated into stage three, condition two into stage two and condition four into stages three and five (refer the proposed model on page 9). Integrating these conditions into the model provides the basis for developing fluency in oral communication.

\section{Accuracy in Oral Communication}

The Applied Linguistics community agrees that accuracy, as opposed to fluency in oral communication (Housen \& Kuiken, 2009) is controversial in nature. Ellis (2009) defines accuracy as "the ability to avoid error in performance, possibly reflecting higher levels of control in the language as well as a conservative orientation, that is, avoidance of challenging structures that might provoke error" (p. 475). Ellis's definition is more likely to serve as a communication strategy ${ }^{[3]}$ rather than accurate language use. On the other hand, accuracy can also be defined as "the absence of deviations from a particular linguistic norm" (Lahuerta, 2017, p. 15), or "correct use of pronunciation, vocabulary and grammar." (Wang, 2014, p. 110). Lahuerta's definition of accuracy is neutral and abstract. Wang's description of accuracy as the correct use of language components contrasts Ellis' definition of accuracy as the ability to avoid the use of complex language to reduce errors in performance.

Be it omission or apposition, the existing consensus regarding the concept of accuracy among linguists is attributed to the precise use of the target language. Hence, accuracy can be defined as using language adequately to meet the target language usage norms of correctness. In addition, the term correctness refers to accurate language usage as prescribed by academic language (Ur, 2011) and "is often emphasized in formal instruction, language acquisition, grammar competence and grammar-translation method" (Shen, 2013, p. 819). In addition to emphasizing grammar competence, accuracy in EFL oral proficiency also requires learners to use accurate pronunciation and vocabulary. Accuracy is also associated with correctness and absence of errors during performance. Chilean EFL university teachers should, therefore, address errors in language use performance through corrective feedback strategies in order to foster learners' (first year EFL pre-service teachers) accuracy in oral communication. 


\section{Corrective FeedBack}

Corrective feedback has attracted considerable interest among SLT researchers (Ferreira, Moore \& Mellish, 2007; Lee, 2013; Loewen, 2012; Lyster, 1998; Lyster \& Ranta, 1997). Corrective feedback "is an indication to a learner that his or her use of the target language is incorrect” (Ferreira et al, 2007, p. 392), which contributes to the learners' awareness regarding correct language use, consequently leading to accurate language use. Corrective feedback "may occur in response to errors in learners' oral or written production” (Loewen, 2012, p. 24). Oral and written feedback are classified as two distinct types of feedback, and, thus, differ in terms of feedback timing and strategies used to deliver these types of feedback.

Since the scope of this article is limited to EFL oral communication, only the following six types of oral corrective feedback strategies are considered: 1) reformulation, 2) explicit correction, 3) clarification request, 4) elicitation, 5) repetition, and 6) metalinguistic feedback (Lyster \& Ranta, 1997). It should be noted that with these strategies, errors are usually corrected immediately during an interaction, which is defined as immediate feedback (Loewen, 2012). However, literature suggests that errors may also be corrected after the learners' production, referred to as delayed feedback (Abello, 2004).

Lyster (1998) grouped various error correction strategies into a single category, which he called negotiation ofform to include elicitation, metalinguistic cues, clarification requests and repetition of errors. Negotiation of form provides learners with timely opportunities to make important form-function links in the target language without interrupting the flow of communication (Lyster, 1998). The author's contribution suggests that a link between fluency and accuracy can be established. Table 1 provides examples and definitions for each oral corrective feedback strategy according to Lyster and Ranta's (1997) classification. 
TABLE 1

Corrective Feedback Types

\begin{tabular}{|c|c|c|}
\hline CF types & Definition & Example \\
\hline $\begin{array}{l}\text { 1. Explicit } \\
\text { correction }\end{array}$ & $\begin{array}{l}\text { Indicates an error } \\
\text { has been } \\
\text { committed, } \\
\text { identifies the error, } \\
\text { and provides the } \\
\text { correction. }\end{array}$ & $\begin{array}{l}\text { S: On May. T: Not on } \\
\text { May, In May. We say, } \\
\text { It will start in May. }\end{array}$ \\
\hline Recast & $\begin{array}{l}\text { Reformulates all or } \\
\text { part of the } \\
\text { incorrect word or } \\
\text { phrase, to show } \\
\text { the correct form } \\
\text { without explicitly } \\
\text { identifying the } \\
\text { error. }\end{array}$ & $\begin{array}{l}\text { S: I have to find the } \\
\text { answer on the book? } \\
\mathrm{T} \text { : In the book. }\end{array}$ \\
\hline $\begin{array}{l}3 . \\
\text { request }\end{array}$ & $\begin{array}{l}\text { Indicates that the } \\
\text { student's } \\
\text { utterance was not } \\
\text { understood and } \\
\text { asks the student to } \\
\text { reformulate it. }\end{array}$ & $\begin{array}{l}\text { S: What do you spend } \\
\text { with your wife? T: } \\
\text { What? (Or, Sorry?) }\end{array}$ \\
\hline $\begin{array}{l}4 . \quad \text { Meta- } \\
\text { linguistic feedback }\end{array}$ & $\begin{array}{l}\text { Gives technical } \\
\text { linguistic } \\
\text { information about } \\
\text { the error without } \\
\text { explicitly } \\
\text { providing the } \\
\text { correct answer. }\end{array}$ & $\begin{array}{l}\text { S: There are influence } \\
\text { person who. } \mathrm{T} \text { : } \\
\text { Influence is a noun. }\end{array}$ \\
\hline Elicitation & $\begin{array}{l}\text { Prompts the } \\
\text { student to self- } \\
\text { correct by pausing } \\
\text { so the student can } \\
\text { fill in the correct } \\
\text { word or phrase. }\end{array}$ & $\begin{array}{l}\text { S: This tea is very } \\
\text { warm. T: It's very? S: } \\
\text { Hot. }\end{array}$ \\
\hline Repetition & $\begin{array}{l}\text { Repeats the } \\
\text { student's error } \\
\text { while highlighting } \\
\text { the error or } \\
\text { mistake by means } \\
\text { of emphatic stress. }\end{array}$ & $\begin{array}{l}\text { S: I will showed you. } \\
\text { T: I will SHOWED } \\
\text { you? S: I'll show you. }\end{array}$ \\
\hline
\end{tabular}

Source: Taken from Lee (2013, p. 218).

Despite the vast amount of research available on this subject, there is a plethora of criteria that can be researched regarding corrective feedback in Communicative Language Teaching, such as, When should learners' errors be corrected? / Which learners' errors should be corrected? How should learners' errors be corrected? and Who should correct learners' errors? However, these questions must be considered according to learners ' characteristics (e.g. personality, educational level) and task type conception (e.g. monolingual, dialogued, number of participants involved). Furthermore, teaching-learning contexts (e.g. academic majors, kind of linguistic communities) and course types (e.g. English as Second/Foreign Language, English for Specific or Academic Purposes) are other variables to be considered. In attempting to answer such questions there are no conclusive answers. Explicit and metalinguistic feedback, for instance, is used in implementing stage four of the proposed didactic model. EFL pre-service teachers are required to manage the target metalanguage and language in general. Thus, their errors should be corrected using metalinguistic feedback complemented with explicit correction to help develop accuracy and awareness of target language use in oral communication. In addition, corrective delayed feedback must be used when learners finish tasks to prevent interrupting the 
flow of communication (fluency). Thus, deciding on the type of feedback strategy and timing selection must concur with the model proposal to balance fluency and accuracy in oral communication among first year EFL pre-service teachers.

\section{Balancing Fluency and Accuracy}

Fluency and accuracy in oral communication is influenced by Second/Foreign Language teaching and learning methodologies. On the one hand, some methodologies are based on a Focus on Forms (accuracy), and others focus on meaning (fluency). According to Nishimura (2000), "grammar translation and audiolingual methods are typical examples, and classroom practices such as repetition of models, drills, and transformational exercises are to be emphasized" (p. 8). Teaching and learning EFL is a skill development process based on forms-focused methodologies. Drills and model repetition practices are used during stage two of the proposed didactic model to foster first year Chilean EFL pre-service teachers' accuracy in oral communication. The main objectives of meaning-focused Second/Foreign Language teaching and learning, include the use of communicative tasks that pursue spontaneous language use in settings that mimic real life situations. Meaning-focused methodologies respond to a Communicative Approach where errors are perceived as a natural part of language acquisition where only errors that affect communication can be corrected. Current variants of the Communicative Approach in Communicative Language Teaching include Task-Based Language Teaching (TBLT)[4] and Focus on Form which foster different approaches to attaining accuracy in grammar when training EFL teachers.

Focus on Forms is described as "systematic teaching of grammatical structures according to a predetermined grammatical syllabus" (Ur, 2011, p. 516) which contrasts with Focus on Form, a methodology that accounts for both fluency and accuracy. According to Ur (2011), Focus on Form implies taking "time out to talk about a particular grammatical form in the course of an otherwise communicative procedure, or paying attention, while focusing on the meaning of a text, to some feature that is salient in its grammar" (2011, p. 516). Focus on Form places equal emphasis on fluency and accuracy; however Focus on Forms (accuracy) is short and inconspicuous, learners' attention is predominantly directed toward the communicative meaning (fluency). The proposed didactic model links Focus on forms and Focus on Form in which the latter triggers the former in order to balance oral communication fluency and accuracy during the EFL teaching-learning process (refer stage four of the model).

The principle methodology used in disrupting the controversy between fluency and accuracy in oral communication is TBLT. Tasks "are believed to foster processes of negotiation of meaning, modification, rephrasing and experimentation that are at the heart of second language learning" (Richards \& Rodgers, 2001, p. 228). In other words, TBLT proposes a balance between fluency and accuracy in oral communication. Furthermore, Skehan (1998) claims that cognitively demanding tasks may be designed to develop both fluency and an awareness of language form (accuracy). Nevertheless, Skehan also emphasizes that "meaning is primary... the assessment of the task is in terms of outcome" (Skehan, 1998, p. 98). Therefore, neither TBLT nor Focus on Form provides the correct balance between fluency and accuracy required to foster attainment of EFL oral communication.

Research on this subject reveals that no Second/Foreign Language teaching methodology sufficiently emphasizes balancing accuracy and fluency in oral communication. To support this claim, Hammerly (1991) suggests that "proficiency without linguistic control is not proficiency but just communicative survival skill. Communication is most effective when it is grammatical, when the attention of the listener is not drawn away from the message to linguistic errors" (p. 44). Therefore, integrating adequate methodologies and classroom practices for fluency and accuracy using the proposed didactic model, can be a successful way to balance fluency and accuracy in oral communication among first year Chilean EFL pre-service teachers. The section of the proposed model (on page 9) shows how this integration can be carried out. 


\section{STATE-OF-THE-ART}

According to Nation (2011), "research on spoken fluency development has shown that the traditional separation between fluency and accuracy activities may not be well justified" (p. 451). The author underscores that development of fluency can also lead to greater accuracy, which is also supported by Albino (2017), Arevart \& Nation, (1991), and Thai \& Boers (2016). Albino conducted a case study to assess how EFL learners improved their speaking fluency through TBLT. Findings indicated that learners improved their speaking fluency by maximizing speed of speech production and increased grammatical accuracy. Therefore, TBLT appears to be a successful methodology for EFL fluency and accuracy development.

Arevart and Nation (1991) developed a research study about use of $4 / 3 / 2$ activity to increase fluency. This activity applies to the pair work method, in which one learner presents a narration to a partner with a fourminute time limit. Next, they switch partners and the same speaker presents the same narration to a new partner with a three-minute time limit. Finally, learners switch partners again and the same speaker presents the same narration for a third time to a new partner with a two-minute time limit (Nation, 2011). It was discovered that speaking fluency had increased in the two-minute narration compared to the four-minute narration, with a reduction in the number of grammatical errors made in the repeated fragments, leading to the conclusion that increased fluency in speech is associated with enhanced accuracy.

Similarly, Thai and Boers (2016) replicated the 4/3/2 activity on twenty Vietnamese EFL learners with or without reducing the time limit. As a result of this study:

Fluency was enhanced most markedly in the shrinking-time condition, but no significant changes regarding complexity or accuracy were attested in that condition. Although the increase in fluency was less pronounced in the constant-time condition, this increase coincided with modest gains in complexity and accuracy. (Thai \& Boers, 2016, p. 369)

Research on EFL fluency development has shown to be successful through TBLT and specifically through task repetition. In addition, accuracy has also been indirectly enhanced, although to a lesser extent and with more SLT research emphasis on accurate language use. Ansarin and Chehrazad (2015) researched the effects of two different Focus on Form feedback strategies, unfocused and focused recasts, on EFL learners oral accuracy. Three pre-intermediate classes were assigned at random: a focused recast group (simple past tense errors correction), an unfocused recast group (all errors correction), and the control group (with no corrective feedback delivered). Findings of the study showed that Focus on Form can be an effective tool for the development of oral accuracy in EFL settings. In addition, the study also shows that recasting learners' oral errors may enhance oral accuracy.

On the other hand, Tabandeh, Moinzadeh, and Barati (2018) conducted a study on the contrasting effects of Focus on Form versus Focus on Forms instruction on improving pronunciation in Iranian EFL learners. While the experimental group was taught through a Focus on Form method, the comparison group received Focus on Forms instruction with controlled and spontaneous tasks assigned in both groups. The control group held a conversation class, receiving no feedback on the target consonants. Results regarding phonemic accuracy showed that, although both Focus on Form and Focus on Forms were equally effective for controlled tasks, only Focus on Form instruction proved to be effective for spontaneous tasks. In addition, no improvements were observed in the control group (Tabandeh et al., 2018, p. 112). According to the results, unobtrusive pronunciation teaching within a communicative spontaneous task improved EFL pronunciation accuracy.

According to Ansarin and Chehrazad (2015) and other authors cited for this literature review (Lee \& Lyster, 2016; Li, Zhu \& Ellis, 2016), most studies on accuracy have focused on oral corrective feedback strategies, not only for improving pronunciation and grammar but for enhanced accuracy in vocabulary use, though to a lesser extent. They also embrace the positive effects of corrective feedback, specifically over the last four years. Recent studies on SLT have found favorable results regarding EFL fluency and accuracy 
development in oral communication. Such studies have found that different methodologies such as TBLT, Focus on Form, Focus on Forms, and practices such as corrective feedback and task repetition have improved fluency and accuracy. However, there is little evidence of methodologies to balance such constructs, which is why providing a balance between fluency and accuracy in EFL oral communication still requires further study.

\section{Model Proposal}

The proposed didactic model is specifically designed to help Chilean instructors teaching first year EFL preservice teachers, address learners' difficulties in balancing both accuracy and fluency in oral communication. The proposed model considers the theoretical foundations and the latest methodologies in addressing fluency and accuracy constructs in oral communication development analyzed herein. The theory-based didactic model is directed specifically at first year learners since their linguistic and communicative skills are still under development. The proposed model is based on a mixed methodology consisting of five stages: 1) Task Planning, 2) Task Practice focused on Forms, 3) Tasks Practice Focused on Meaning, 4) Tasks Practice Combining Focus on Form and Focus of Forms, and 5) Integrated Tasks Practice. The model uses tasks as the turning point in the teaching-learning process, allowing learners to move from systematic practice to automated language use. Figure 1 depicts the five stages of the proposed didactic model.

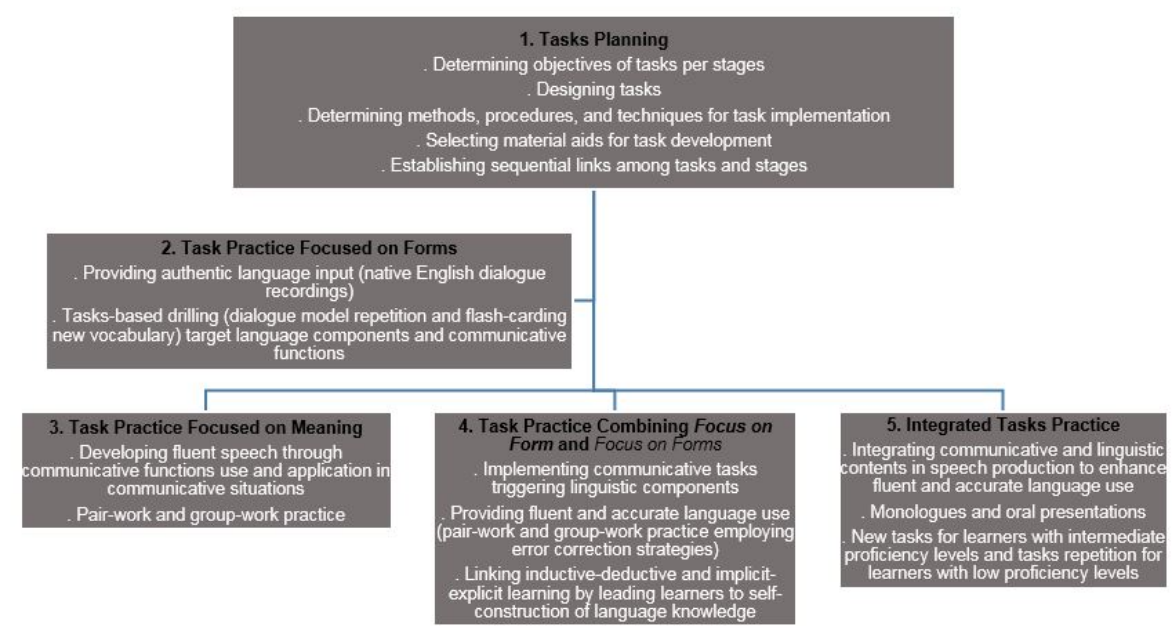

FIGURE 1

Five-Stage Sequenced Theory-Based Didactic Model

to Balance Fluent and Accurate Oral Communication.

Note: Diagram depicting the proposed model

Source: Original diagram

1- Task Planning: This is one of the most important stages of the model that includes teachers only. During this stage, teachers design all of the tasks for stages 2 through 5 , requiring that material from the entire unit will be included, based on the syllabus. Teachers must determine the objectives of each stage based on the thematic and linguistic contents as well as create an interrelated sequence of tasks and stages that prepares learners for the final stage. At this point, it is essential that teachers determine the necessary communicative and linguistic support material such as visual aids, methods, procedures, and techniques for tasks implementation and development.

2- Tasks Practice Focused on Forms: This is the initial stage of the sequence that brings in learners. This stage provides learners with the general thematic and linguistic content used throughout the remaining stages. Authentic language input is provided through native English dialogue recordings in order to introduce 
the target language (new vocabulary, grammar points, and syntax) of the unit. Drilling tasks such as repetition (choral, in pairs) of a model dialogue and flash-carding new words provide learners with an accurate use of vocabulary, grammar, and pronunciation as well as intonation patterns and communicative functions.

3- Tasks Practice Focused on Meaning: This stage focuses on the development of communicative functions identified from the dialogues used in the first stage. Teachers create communicative situations contextualized to daily life so that learners can apply them to communicative tasks practice. Communicative situations are conceived and implemented requiring incremental use of the communicative functions. First, a communicative function is integrated into a communicative situation. Next, two communicative functions are integrated into a communicative situation, followed by three and so on until all of the communicative functions are integrated into a single situation, a communicative situation in which the full integration is possible. Thus, the more practice and repetition of communicative functions, the greater the amount of fluency development. This type of practice requires pair-work or group-work according to the needs of the communicative situations. This stage pursues the development of fluent oral communication through meaning oriented tasks. Table 2 below illustrates the implementation of this stage of the model. 
TABLE 2

Example of Tasks Practice Implementation Focused on Meaning

\begin{tabular}{ll}
\hline Communicative Functions & Communicative Situations \\
\hline 1. Cancel plans & Learner A: You were planning to go to \\
E.g. Learner A: I 'm sorry to let you down, & the movies with your sister, but you \\
but I can't go to the concert tonight. I have & remembered you have a big exam \\
too much work to do. Learner B: That's O. & tomorrow that you haven't started \\
K. I understand. & studying for. Cancel your plans. \\
& Learner B: You and your brother were \\
& planning to go to the movies, but he \\
& remembered he has a big exam \\
& tomorrow so he canceled your plans. \\
& Give him advice. \\
\hline
\end{tabular}

2. Give advice

E.g. Learner A: Meg's on the phone right

now.

Learner B: Maybe you'd better not

interrupt her, then.

3. Ask permission E.g. Learner A:

Would you mind if I opened the window?

It's getting stuffy in here.

Learner B: Not at all. Go right ahead.

\author{
Learner A: You are reading an article for \\ school when your friend arrives at your \\ house to pick you up for your date with \\ his sister but you haven't gotten dressed \\ yet. Ask him for a favor. \\ Learner B: You just arrived at your \\ friend's house to pick him up for a date \\ he has with your sister but he hasn't \\ gotten dressed yet and your sister is \\ waiting for him. Ask about an \\ obligation, give him advice.
}

$4 . \quad$ Ask someone for a favor

E.g. Learner A: I'd really appreciate it if you could help me type my paper tonight. Learner B: I really wish I could, but I have to work.

\begin{tabular}{ll}
\hline 5. Ask about an obligation & Learner A: You are calling your \\
E.g. Learner A: What time are we supposed & girlfriend at work, but it is lunch time \\
to meet Carla and Rob? & and the secretary answers the phone. \\
Learner B: At six... & Ask her for a favor, Ask about an \\
& obligation. While you are talking to the \\
secretary, your girlfriend arrives and \\
answers the phone, cancel plans (the \\
date planned). \\
Learner B: You are a secretary and the \\
phone rings. You are asked to look for a \\
coworker, but she is not there right now, \\
so give advice. You can't hear very well \\
so ask for a favor. While you are \\
speaking on the phone you notice your \\
coworker is talking in the hall so ask her \\
for permission. You should also act out \\
the role of your coworker, so answer \\
your boy friend's call and ask about an \\
obligation (the date planned).
\end{tabular}

Note: Table illustrating implementation of Stage Three of the model Source: Based on Warshawsky and Costinett (1982). 
4- Tasks Practice Combining Focus on Form and Focus on Forms: Stage four provides both fluent and accurate language use. Tasks in this stage are consciously designed by English language teachers in order to trigger the use of linguistic forms from the unit within a communicative context. For instance, a unit topic may be use of the third person singular in the simple present, a task may include narrating someone else's daily routines or reciting anecdotes/narrations for the use of past tense verbs. Communicative tasks processes are complemented by using corrective feedback strategies (metalinguistic and explicit correction) not only for grammatical errors, but also to correct the mispronunciation of the target morphemes: /s/, /es/, and /ed/. Learners may be assigned to correct errors among themselves and teachers can lead them in constructing the grammar and pronunciation rules on their own, thereby fostering correct language use through learners' self-construction of knowledge and learning. Table 3 shows the implementation of this stage of the model (stage four). 
Yaynel González Robaina, et al. Proposing a Theoretical and State-of-the-Art Didactic Model to Bal...

TABLE 3

Example of Tasks Practice Implementation Combinig Focus on Forms and Focus on Forms

\begin{tabular}{|c|c|c|c|c|}
\hline Task & $\begin{array}{l}\text { Narrating } \\
\text { someone } \\
\text { else's daily } \\
\text { routines }\end{array}$ & & & \\
\hline Form & $\begin{array}{l}\text { Third person } \\
\text { singular } \\
\text { verbs in } \\
\text { present } \\
\text { simple } \\
\text { affirmative } \\
\text { statements }\end{array}$ & & & \\
\hline Learners' Role & $\begin{array}{l}\text { While a } \\
\text { learner } \\
\text { performs the } \\
\text { task, the rest } \\
\text { of the } \\
\text { learners are } \\
\text { listening and } \\
\text { taking notes } \\
\text { of any } \\
\text { errors. At the } \\
\text { end, explicit } \\
\text { and } \\
\text { metalinguistic } \\
\text { correction } \\
\text { feedback will } \\
\text { be given by } \\
\text { the learners } \\
\text { to learner } \\
\text { who } \\
\text { performed } \\
\text { the task }\end{array}$ & & & \\
\hline Teacher's Actions & $\begin{array}{l}\text { 1. While one } \\
\text { of the } \\
\text { learners } \\
\text { performs the } \\
\text { assigned } \\
\text { task, the } \\
\text { teacher } \\
\text { must also } \\
\text { take notes of } \\
\text { any errors. } \\
\text { During the } \\
\text { feedback } \\
\text { session, the } \\
\text { teacher must } \\
\text { not interrupt } \\
\text { while the } \\
\text { other } \\
\text { students are } \\
\text { giving their } \\
\text { feedback. } \\
\text { The teacher } \\
\text { may only } \\
\text { interfere if } \\
\text { learners miss } \\
\text { any error's or } \\
\text { if incorrect } \\
\text { feedback is } \\
\text { provided. }\end{array}$ & $\begin{array}{l}\text { 2. As } \\
\text { expected, } \\
\text { the } \\
\text { most } \\
\text { frequent } \\
\text { error is } \\
\text { the third } \\
\text { person } \\
\text { singular } \\
\text { in the } \\
\text { simple } \\
\text { present } \\
\text { tense. } \\
\text { The } \\
\text { teacher } \\
\text { should } \\
\text { direct } \\
\text { learners' } \\
\text { attention } \\
\text { to the } \\
\text { error } \\
\text { and } \\
\text { discuss } \\
\text { the rule } \\
\text { of that } \\
\text { specific } \\
\text { linguistic } \\
\text { form. }\end{array}$ & $\begin{array}{l}\text { 3. After } \\
\text { writing } \\
\text { different } \\
\text { examples of } \\
\text { the form on } \\
\text { the board, } \\
\text { the teacher } \\
\text { will guide } \\
\text { learners in } \\
\text { constructing } \\
\text { grammar } \\
\text { and } \\
\text { pronunciation } \\
\text { rules by } \\
\text { asking } \\
\text { questions. (E. } \\
\text { g. What } \\
\text { happens to } \\
\text { the end of } \\
\text { these verbs? } \\
\text { /What do we } \\
\text { add at the } \\
\text { end? / When } \\
\text { do we } \\
\text { add - es? } \\
\text { / When do } \\
\text { we add - } \\
\text { ies? /How do } \\
\text { we } \\
\text { pronounce } \\
\text { those } \\
\text { endings?) } \\
\end{array}$ & $\begin{array}{l}\text { 4. The teacher } \\
\text { should ask the } \\
\text { learners to } \\
\text { work in groups } \\
\text { to establish the } \\
\text { grammar and } \\
\text { pronunciation } \\
\text { rules of the } \\
\text { third person } \\
\text { singular verbs } \\
\text { in present } \\
\text { simple } \\
\text { affirmative } \\
\text { statements. } \\
\text { The } \\
\text { established } \\
\text { rules are then } \\
\text { compared and } \\
\text { the most } \\
\text { complete rule } \\
\text { is stated out } \\
\text { loud for the } \\
\text { rest of the } \\
\text { learners } \\
\text { to copy. The } \\
\text { teacher may } \\
\text { only } \\
\text { interfere if any } \\
\text { of the rules } \\
\text { are incomplete. }\end{array}$ \\
\hline
\end{tabular}


Note: Table illustrating the implementation of Stage Four of the model. Source: Original Table

5- Integrated Tasks Practice: The final stage incorporates all communicative and linguistic contents included in the unit to practice correct grammar, vocabulary, and pronunciation in fluent oral production as a communicative task. Tasks for this stage can be conceived as monologues or oral class presentations. Learners with intermediate proficiency levels can practice new tasks and learners with low proficiency levels can repeat Stage Four tasks. The greater the number of repetitions, the greater the amount of fluency and accuracy development attained. With further practice, learners can develop fluent and accurate language use in oral communication.

The proposed didactic model integrates language teaching methodologies (TBLT, Communicative Language Teaching, Focus on Forms, Focus on Form ) that distinguishes accurate versus fluent language use in oral communication. Adequate classroom practices (drilling, pair and group work, corrective feedback, task repetition, monologues, and oral presentations) were combined in this model, as evidenced in the different stages of the model ( Figure 1 ), implementation of the EFL Oral Training model allows learners to move through the learning process from: input to output, inductive to deductive, implicit to explicit, and eventually from systematic practice to automated language use, keeping in mind that automaticity is never fully attained in nonnative speakers.

The model contributes to EFL teaching and learning by providing adequate conditions for learners to balance fluent and accurate oral communication development, helping them become proficient English language users. It is important to consider that even though this model was conceived for first year Chilean EFL pre-service teachers, these concepts are applicable to first and second year learners majoring in English as a Second/Foreign Language at any university around the world. However, since no group of learners or teachers are all alike, establishing the model's effectiveness is challenging. For best results, it is necessary to adjust the model to learners' characteristics and the actual teaching-learning context.

\section{Conclusions}

This article proposes a theory-based didactic model to reduce constraints associated with fluency and accuracy balance in oral communication development. Being able to strike a balance between fluent and accurate EFL use in oral communication is difficult since these constructs remain separate in Second/Foreign Language teaching theories, methodologies, and approaches. Consequently, certain aspects of language have always been prioritized, although erroneously (meanings over forms or vice versa, for example). English syllabi have separated classroom practices and activities in order to focus on fluency or accuracy. Establishing a connection between those constructs in EFL teaching and learning is imperative for improving learners' oral communication abilities.

Although literature highlights the complexity of obtaining such a balance in oral fluency and accuracy, from a methodological perspective; the proposed didactic model for EFL university teachers willing to face this challenge, suggests linking fluency and accuracy through tasks that focus equally both constructs. Tasks are conceived with an overall communicative (meaning) purpose and also triggers linguistic (forms) components. Implementing tasks based on real-life communicative situations such as reciting anecdotes, in which linguistic forms (e.g. past tense verbs) are applied, can help balance EFL fluency and accuracy in oral communication. Pair and group work techniques along with the learners' own feedback and teachers' strategies used to help learners construct EFL pattern rules, can provide first year Chilean EFL pre-service teachers with negotiation of meaning (fluency) and forms (accuracy) during tasks development. Therefore, the proposed didactic model that balances fluent and accurate oral communication, contributes to the progression of such constructs' balance in EFL oral communication learning and teaching. More research 
is necessary, which address balancing oral fluency and accuracy in EFL pre-service teachers training, an important area in SLT.

\section{REFERENCES}

Abello, Ch. (2004). Bases pedagógicas para el uso del feedback negativo en el aula de español como L2. En R. Ruhstaller. (Ed.), La competencia lingüistica y comunicativa en el aprendizaje del español como lengua extranjera (pp. 71-82). Madrid, España: Edinumen.

Albino, G. (2017). Improving Speaking Fluency in a Task-Based Language Teaching Approach: The Case of EFL Learners at PUNIV-Cazenga. SAGE Journal, 7(2), 1-11. doi: https://doi.org/10.1177\%2F2158244017691077

Ansarin, A., \& Chehrazad, M. (2015). Differential effects of focused and unfocused recasts on the EFL learners' oral accuracy. Colomb. Appl. Linguist. J., 17(1), 86-97. doi: https://doi.org/10.14483/udistrital.jour.calj.2015.1.a06

Arevart, S., \& Nation, I.S.P. (1991). Fluency improvement in a second language. RELC Journal, 22(1), 84-94. doi: h ttps://doi.org/10.1177/003368829102200106

Doughty, C., \& Williams, J. (2009). Problemas y terminología. En C. Doughty \& J. Williams. (Ed.), Atención a la forma en la adquisición de segundas lenguas en el aula (pp. 15-26). Madrid, España: Edinumen.

Ellis, R. (2003). Task-based Language Learning and Teaching. New York, USA: Cambridge University Press.

Ellis, R. (2009). The Differential Effects of Three Types of Task Planning on the Fluency, Complexity, and Accuracy in L2 Oral Production. Applied Linguistics, 30(4), 474-509. doi: https://doi.org/10.1093/applin/amp042

Ferreira, A., Moore, J., \& Mellish, Ch. (2007). A study of Feedback Strategies in Foreign Language Classrooms and Tutorials with Implications for Intelligent Computer Assisted Language Learning Systems. International Journal in Intelligent Artificial in Education (IJAIED), 17(4), 389 - 422. Retrieved from https://bit.ly/2y98ts1

Hammerly, H. (1991). Fluency and Accuracy: Toward Balance in Language Teaching and Learning. Clevedon, UK: Multilingual Matters Ltd.

Housen, A., \& Kuiken, F (2009). Complexity, Accuracy and Fluency in Second Language Acquisition. Applied Linguistics, 30(4), 1-22. doi: https://doi.org/10.1093/applin/amp048

Karimy, S., \& Pishkar, K. (2017). The Relationship among ELT Students' Speaking Accuracy and Fluency and Teachers' Oral Skill Class Presentation. Journal of Applied Linguistics and Language Research, 4(2), 47-56. Retrieved from http://www.jallr.com/index.php/JALLR/article/view/533/pdf533

Lahuerta, A. C. (2017). Analysis of Accuracy and Grammatical Complexity in the Writing of Upper Intermediate and Advance Learner of English. RLA. Revista de lingüistica teórica y aplicada, 55(1), 13-33. doi : https://doi.o $\mathrm{rg} / 10.4067 /$ S0718-48832017000100013

Lee, A., \& Lyster, R. (2016). Effects of Different Types of Corrective Feedback on Receptive Skills in a Second Language: A Speech Perception Training Study. Language learnig, 66(4), 809-833. doi : https://doi.org/10.11 11/lang. 12167

Lee, E. J. (2013). Corrective feedback preferences and learner repair among advanced ESL students. System, 41(2), 217-230. doi: https://doi.org/10.1016/j.system.2013.01.022

Lennon, P. (1990). Investigating fluency in EFL: A quantitative approach. Language Learning, 40(3), 387-417. doi: https://doi.org/10.1111/j.1467-1770.1990.tb00669.x

Li, S., Zhu, Y., \& Ellis R. (2016). The Effects of the Timing of Corrective Feedback on the Acquisition of a New Linguistic Structure. The Modern Languge Journal, 100(1), 276-295. doi : https://doi.org/10.1111/modl.12315

Littlewood, W. (2004). Second Language Learning. In A. Davies. \& C. Elder. (Eds.), The handbook of applied linguistics (pp. 501-524). London, UK: Blackwell Publishing Ltd.

Lizasoain, A., Ortiz de Zárate, A., Véliz, M., Luci, A., \& Rojas, J. (2016). Evaluation of It's My Turn, a self-learning interactive tool to study English in Chilean rural contexts. Calidad en la educación, (44), 98-128. doi: https:// doi.org/10.4067/S0718-45652016000100005 
Loewen, S. (2012). The role of feedback. In S. Gass. \& A. Mackey. (Ed.), Handbook of second language acquisition (pp. 24-41). New York, USA: Routledge.

Lyster, R. (1998). Negotiation of Form, Recasts, and Explicit Correction in Relation to Error Types and Learner Repair in Immersion Classrooms. Language Learning, 48(2), 182-218. doi: https://doi.org/10.1111/1467-99 22.00039

Lyster, R., \& Ranta, L. (1997). Corrective Feedback and Learner Uptake: Negotiation of Form in Communicative Classrooms. Studies in Second Language Acquisition, 19(1), 37-66. doi: https://doi.org/10.1017/S027226319 7001034

Macaro, E. (2003). Teaching and Learning a Second Language: A Guide to Recent Research and its Applications. London, UK: Continuum.

Nation, I.S.P. (2011). Second Language Speaking. In E. Hinkel., Handbook of Research in Second Language Teaching and Learning (pp. 444-454). New York, USA: Routledge.

Nishimura, K. (2000). Effective Ways of Communicative Instruction in the Japanese EFL Classroom: Balancing Fluency and Accuracy. ERIC. Retrieved from http://files.eric.ed.gov/fulltext/ED442297.pdf

Požgaj, V., Horga, D., \& Balazic, T. (2012). Speech fluency: a result of oral language proficiency? Linguistica, 52(1), 87-100. doi: https://doi.org/10.4312/linguistica.52.1.87-100

Richards, J. C., \& Rodgers, T. (2001). Approaches and Methods in Language Teaching. Cambridge, UK: Cambridge University Press.

Segalowitz, N., \& Freed, B. (2004). Context, Contact, and Cognition in Oral Fluency Acquisition: Learning Spanish in at Home and Study Abroad Contexts. Studies in Second Language Acquisition, 26(2), 173-199. doi: https:// doi.org/10.1017/S0272263104262027

Shen, Y. (2013). Balancing Accuracy and Fluency in English Classroom Teaching to Improve Chinese NonEnglish Majors 'Oral English Ability. Theory and Practice in Language Studies, 3(5), 816-822. doi : https://doi.org/10 $.4304 / \mathrm{tpls.3.5.816-822}$

Skehan, P. (1998). A Cognitive Approach to Language Learning. Oxford, UK: Oxford University Press.

Tabandeh, F., Moinzadeh, A., \& Barati, H. (2018). Tasks in Explicit L2 Pronunciation Instruction: FonF vs. FonFS in Improving Phonemic Accuracy and Comprehensibility. 3L: The Southeast Asian Journal of English Language Studies, 24(1), 112-127. doi : https://doi.org/10.17576/3L-2018-2401-09

Thai, C., \& Boers, F. (2016). Repeating a Monologue Under Increasing Time Pressure: Effects on Fluency, Complexity, and Accuracy. TESOL QUARTERLY, 50(2), 369-393. doi : https://doi.org/10.1002/tesq.232

Ur, P. (2011). Grammar teaching: Research, Theory and Practice. In E. Hinkel. Handbook of Research in Second Language Teaching and Learning (pp. 507-522). New York, USA: Routledge.

Wang, Z. (2014). Developing Accuracy and Fluency in Spoken English of Chinese EFL Learners. English Language Teaching, 7(2), 110-118. doi: https://doi.org/10.5539/elt.v7n2p110

Warshawsky, D., \& Costinett, S. (1982). Spectrum: a communicative course in English. New York, USA: Regents.

Yilorm, Y. (2016). The teaching-learning process of English as a foreign language in Chilean Public Schools: Production or reproduction? Estudios pedagógicos, 42, 103-116. doi : https://doi.org/10.4067/S0718-070520 16000300009

\section{Notas}

[1] Research grant: VRID 219003002-1.0: English assessment: knowledge, perceptions, affective dispositions and social representations. A systemic view of the assessment process from in-service and pre-service teachers of English, students, authorities and parents.

[2] Proyecto de investigación: VRID 219003002-1.0: La evaluación del inglés: conocimientos, percepciones, disposiciones afectivas y representaciones sociales. Una mirada sistémica del proceso evaluativo desde los profesores y futuros profesores de inglés, estudiantes, autoridades y apoderados. 
Yaynel González Robaina, et al. Proposing a Theoretical and State-of-the-Art Didactic Model to Bal...

[3] "Communication strategies are, in essence, deployed to solve the problems that L2 speakers encounter in interaction when they do not have enough linguistic knowledge to communicate the intended message as easily as they would in their first language" (Macaro, 2003, p. 211).

[4] "TBLT is motivated primarily by a theory of learning rather than a theory of language. However, several assumptions about the nature of language can be said to underlie current approaches to TBLT” (Richards \& Rodgers, 2001, p. 226).

\section{BY-NC-ND}

